\title{
Effect of the administration of probiotic Bacillus NP5 in the rearing media on water quality, growth, and disease resistance of African catfish (Clarias gariepinus)
}

\author{
ACHMAD NOERKHAERIN PUTRA ${ }^{1,2, \boldsymbol{v}}$, MAS BAYU SYAMSUNARNO ${ }^{1}$, WIDIA NINGRUM ${ }^{1}$, JUMYANAH $^{1}$, \\ MUSTAHAL ${ }^{1}$ \\ ${ }^{1}$ Department of Fisheries, Faculty of Agriculture, Universitas Sultan Ageng Tirtayasa. Jl. Raya Jakarta Km. 4, Pakupatan, Serang 42121, Banten, \\ Indonesia. Tel.: +62-254-280330, Fax.: +62-254-281254. `email: Putra.achmadnp@untirta.ac.id \\ ${ }^{2}$ Indonesia-Center of Excellence for Food Security, Universitas Sultan Ageng Tirtayasa. J1. Raya Jakarta Km. 4, Pakupatan, Serang 42121, Banten, \\ Indonesia
}

Manuscript received: 29 February 2020. Revision accepted: 15 May 2020.

\begin{abstract}
Putra AN, Syamsunarno MB, Ningrum W, Jumyanah, Mustahal. 2020. Effect of the administration of probiotic Bacillus NP5 in the rearing media on water quality, growth, and disease resistance of African catfish (Clarias gariepinus). Biodiversitas 21: 25662575. The purpose of this study was to investigate the effect of administration of the probiotic Bacillus NP5 in rearing media on water quality, growth, and disease resistance of African catfish. The study consisted of three different concentrations of probiotic Bacillus NP5 - C: control, A: probiotic Bacillus NP5 of $1 \times 10^{9} \mathrm{CFU} / \mathrm{mL}$, and B: probiotic Bacillus NP5 of $1 \times 10^{10} \mathrm{CFU} / \mathrm{mL}$, on the rearing media of African catfish for 45 days. Based on the results, the lowest significant ammonia $(\mathrm{P}<0.05)$ was found in treatment $\mathrm{A}(1.91 \pm 0.17$ $\mathrm{mg} / \mathrm{L})$, then followed by B $(2.12 \pm 0.14 \mathrm{mg} / \mathrm{L})$ while the highest was in the control $(2.36 \pm 0.19 \mathrm{mg} / \mathrm{L})$. Treatment A also had a better immune response compared to other treatments shown with the highest significant number of leukocytes at $6.69 \pm 0.17 \times 10^{4} \mathrm{cells} / \mathrm{mm}^{3}$ and phagocyte activity at $65.19 \pm 0.04 \%$. Furthermore, treatment A significantly resulted in the best specific growth rate and feed conversion ratio $\left(2.02 \pm 0.07 \%\right.$.day $^{-1}, 1.05 \pm 0.07$, respectively). The administration of probiotic Bacillus NP5 of $1 \times 10^{9} \mathrm{CFU} / \mathrm{mL}$ in rearing media significantly improved the ammonia value, growth, and resistance of African catfish to Aeromonas hydrophila infection.
\end{abstract}

Keywords: Bacillus NP5, Clarias gariepinus, disease-resistant, probiotic, water quality

\section{INTRODUCTION}

Clarias gariepinus, commonly known as African catfish, is a species of fish widely cultivated in Indonesia (Ngaddi et al. 2019; Iswanto et al. 2019; Nasrulloh et al. 2019) with the production of over 19 thousand tons in 2017 (Ministry of Marine Affairs and Fisheries of the Republic of Indonesia 2019). Based on a report released by FAO in 2018, various intensive fish culture systems have been carried out which help in meeting up for the increasing demands for fish. In intensive culture systems, fish are more easily stressed because fish are reared in high density (Cerezuela et al. 2012; Giri et al. 2014) and many accumulations of organic matter originating from leftover feed and feces (Ren et al. 2019). Also, a study conducted by Widanarni et al. (2010) revealed that the accumulation of organic waste generally in this system with high fish density and feed inputs. Similarly, Avnimelech and Ritvo (2003) reported that $75-80 \%$ of the feed is excreted into the water in the form of ammonia, considering the fact that fish only assimilate $20-25 \%$ in their body. The presence of ammonia in water further increase fish's susceptibility to bacterial infection and could lead to mass death at concentration > $0.2 \mathrm{mg} / \mathrm{L}$ (Boyd and Mcnevin 2014). Also, research by Wang et al. (2008), showed that lack of quality water is a major cause of mass death in intensive fish culture. Zhang et al. (2016) and Garcia-Mendoza et al.
(2019) also reported that the health status of fish and shrimp depends on water quality. Poor water quality directly influences fish metabolism, such as decreased growth, stress, increasing the general mortality, and also thereby leading to the spread of disease outbreaks (Xiong et al. 2016). In addition, disease control in intensive aquaculture is a current issue that has ultimately affect the economy of the country (Nandi et al. 2017). Hence, creating a friendly environment in terms of providing quality water to prevent disease attacks (Ramadhani et al. 2019; Amin et al. 2019).

According to Gomez-Gil et al. (2000) and Kuebutornye et al. (2019), the probiotic is an environmentally friendly method with improved water quality, thereby increasing fish immunity against pathogenic attacks. In clear terms, probiotic is an additional living microbe which could benefit its host by improving microbial balance in the digestive tract (Makled et al. 2019; Zhao et al. 2019; Darafsh et al. 2019; Arani et al. 2019; Valipour et al. 2019), increasing feed use or nutritional value, as well as the host response to disease through improved water quality (Verschure et al. 2000). Also, Devaraja et al. (2013) reported that the provision of probiotics helped in improving the quality of water in vannamei shrimp ponds through the mechanism of bioremediation. Based on research conducted by Dawood et al. (2018), bioremediation is the process of decomposing harmful 
organic wastes in waters using microorganisms. The application of probiotics in various aquaculture systems has been reported to increase water quality through bioremediation of organic waste in water, thereby reducing the growth of pathogenic bacteria (Nimrat et al. 2012; Devaraja et al. 2013; Zorriehzahra et al. 2016; Chumpol et al. 2017; Elsabagh et al. 2018). The methods of providing probiotic in either rearing media (Kewcharoen and Srisapoome 2019; Zhang et al. 2019; Xie et al. 2019) or feed (Jang et al. 2019; Yang et al. 2019; Tachibana et al. 2019; Tsai et al. 2019) have been found to minimize the occurrence of pathogen attacks and water quality degradation.

Similarly, the results of previous studies showed that applying probiotic Bacillus NP5 could increase the growth and activity of proteolytic, lipolytic, and amylolytic enzymes of African catfish (Putra and Romdhonah 2019). According to Putra and Widanarni (2015), the probiotic Bacillus NP5 is usually isolated from the digestive tract of tilapia which has passed the stages of the probiotic selection process. The research conducted by Tamamdusturi et al. (2016) found that the addition of probiotic Bacillus NP5 in the feed could increase the growth and immune response of Pangasianodon hypophthalmus catfish against A. hydrophila infection. Other positive applications of this bacteria in the diet have been found to improve growth performance in tilapia fish (Utami et al. 2015; Putra et al. 2015; Agung et al. 2015), vannamei shrimp (Widanarni et al. 2014) and improve the immune response of the shrimp against white spot syndrome virus (WSSV) attacks (Febrianti et al. 2016). However, no research has shown the role of probiotic Bacillus NP5 in the rearing media of fish culture. Therefore, this study aimed to investigate the effect of the administration of the probiotic Bacillus NP5 on water quality, growth, and disease resistance of African catfish in the rearing media.

\section{MATERIALS AND METHODS}

\section{Culture of probiotic Bacillus NP5}

Isolates of the probiotic Bacillus NP5 were obtained from the Laboratory of Fish Health, Bogor Agricultural University. A total of $250 \mathrm{~mL}$ of TSB (Tryptic soy broth) media was prepared and isolate of Bacillus NP5 bacterium was inoculated on it and incubated for 18 hours at $29^{\circ} \mathrm{C}$ (Putra and Romdhonah 2019). Next, the freshly harvested culture was centrifuged at a speed of $1000 \mathrm{~g}$ for 10 minutes. Then probiotics were diluted serially by adding Phosphate Buffered Saline (PBS) based on different treatments (Nurhayati et al. 2015), after which these diluted samples were given to the catfish through the rearing media.

\section{Experimental design}

This study was conducted at Wet Laboratory, Department of Fisheries, Faculty of Agriculture, University of Sultan Ageng Tirtayasa. The African catfish used were the seeds from the Baros Fish Seed Center (BBI Baros),
Serang Regency, Banten. Each fish with an average weight of $8.06 \pm 0.06 \mathrm{~g}$ were reared for 45 days using a round tank with a diameter of $71 \mathrm{~cm}$ and a height of $53.5 \mathrm{~cm}$ involving $20 \mathrm{fish} / \mathrm{tank}$. The fish acclimation was carried out for 5 days before to the rearing process. Experimental fish were fed the commercial feed with a protein content of $30 \%$ and fed to fish three times a day (08: 00, 12: 00, 16: 00 Western Indonesia Time) up to satiation. In addition, the water purification and replacement processes were not carried out during rearing. The study design was the completely randomized design consisting of three treatments with different concentrations of the probiotics on the rearing media and three replications, namely:

C: control

A: probiotic Bacillus NP5 of $1 \times 10^{9} \mathrm{CFU} / \mathrm{mL}$

B: probiotic Bacillus NP5 of $1 \times 10^{10} \mathrm{CFU} / \mathrm{mL}$

\section{The challenge test}

The pathogenic bacteria used, A. hydrophila, was obtained from the Laboratory of Fish Health, IPB University. Then, Koch's postulate was carried out to increase its virulence. Furthermore, A. hydrophila was inoculated in $50 \mathrm{~mL}$ TSB media and then incubated at 20 ${ }^{\circ} \mathrm{C}$ for 24 hours. The bacterial culture was subsequently centrifuged at $1000 \mathrm{~g}$ for 10 minutes and then diluted to a density of $10^{7} \mathrm{CFU} / \mathrm{mL}$ through the addition of PBS. The pathogenic bacterium was then injected into catfish intramuscularly (Putra and Widanarni 2015) at a dose of $10^{7} \mathrm{CFU} / \mathrm{mL}$. The wound formed due to this was scratched on the TSA media using the quadrant scratch method.

Subsequently, Lethal Doses $50 \%\left(\mathrm{LD}_{50}\right)$ was performed to obtain the amount of the bacteria used in the challenge test. $\mathrm{LD}_{50}$ is the pathogen needed to kill $50 \%$ of the total catfish population. In addition, the pathogenic bacterium was inoculated on $100 \mathrm{~mL}$ TSB media, then incubated at $20{ }^{\circ} \mathrm{C}$ for 24 hours. Further, the bacterial culture was centrifuged at $1000 \mathrm{~g}$ for 10 minutes to obtain fresh samples and then given the catfish rearing media with 3 different doses - $10^{5} \mathrm{CFU} / \mathrm{mL}, 10^{6} \mathrm{CFU} / \mathrm{mL}$, and $10^{7}$ $\mathrm{CFU} / \mathrm{mL}$. After 10 days of observation, the test results showed that the treatment with a dose of $10^{6} \mathrm{CFU} / \mathrm{mL}$ had a survival rate of $55 \%$. Hence, the sample with a dose of $10^{6} \mathrm{CFU} / \mathrm{mL}$ was used in the challenge test.

The challenge test was carried out after 30 days of rearing period with the addition of probiotic Bacillus NP5 in the rearing media. The A. hydrophila isolate was inoculated on $200 \mathrm{~mL}$ TSB media and then cultured on a water bath shaker at $29^{\circ} \mathrm{C}$ for 24 hours. Furthermore, the bacterial culture was centrifuged at a speed of $1000 \mathrm{~g}$ for 10 minutes after which the fresh culture was further diluted using PBS to a density of $10^{6} \mathrm{CFU} / \mathrm{mL}$ and given to catfish rearing media.

\section{Water quality parameters}

The water quality sampling was carried out on days 0 , $10,20,30,34,38$ and 45 which involved the measurements of temperature and Dissolved Oxygen (DO) with the use of a DO meter with a brand of Luxtron DO550, and $\mathrm{pH}$ using a pH meter with a type of luxtron 208, in-situ manner. The ammonia measurements were carried out at the Laboratory 
of Aquaculture, Department of Fisheries, Faculty of Agriculture, University of Sultan Ageng Tirtayasa. A sample of $100 \mathrm{~mL}$ of water was taken from each container and measured using a spectrophotometer AMV01 through the Phenate standard method following with APHA (1988).

\section{Growth parameters}

The growth sampling was carried out on Day 30 before the challenge test and at the end of the culture or after the challenge test (Day 45). The fish were weighed and counted at the beginning and end of the rearing process to calculate the value of the Specific Growth Rate (SGR) and Survival Rate (SR). The amount of both the initial and final feeds were weighed to obtain the value of total feed consumption (FI) and Feed Conversion Ratio (FCR). Calculations of SGR, SR, FI, and FCR were in accordance with Huisman (1987) as follows:

$\operatorname{SGR}\left(\%\right.$ day $\left.^{-1}\right)=((\mathrm{Ln} \mathrm{Bt}-\mathrm{Ln} \mathrm{Bo}) / \mathrm{P}) \times 100$

$\mathrm{SR}(\%)=(\mathrm{Et} / \mathrm{Eo}) \times 100$

$\mathrm{FI}(\mathrm{g})=\mathrm{Ft}-\mathrm{Fo}$

$\mathrm{FCR}=\mathrm{FI} /(\mathrm{Bt}+\mathrm{Bd}-\mathrm{Bo})$

Note: $\mathrm{Bt}$ : $\mathrm{t}$-th biomass of fish, Bo: initial biomass of fish, Et: t-th number of fish, P: time (days), Eo: initial number of fish, Ft: t-th amount of feed, Fo: the initial amount of feed, Bd: biomass of dead fish.

\section{Hematological parameters}

A total of 3 fish from each treatment was selected and blood samples were taken on days 0, 30 (before the challenge test) and 45 (after the challenge test), with a syringe already containing anti-coagulant, $0.1 \mathrm{~mL}$ of $3.8 \%$ $\mathrm{Na}$ citrate. Furthermore, blood profile consisting of hematocrit and hemoglobin levels, total erythrocytes and leukocytes, and phagocytic activity were calculated with the aid of a microscope. Determination of hematocrit levels and phagocytic activity were in accordance with Anderson and Siwicki (1995) method, hemoglobin levels were measured through the Sahli method in Wedemeyer and Yasutake (1977), and the total erythrocytes and leukocytes were following Blaxhall and Daisley (1973) method.

\section{Histopathology}

Histology was carried out to evaluate the level of organ damage due to pathogen attacks based on the method described by Wada et al. (2011). Its preparation was made at the Histopathology Laboratory, Fish and Environmental Disease Examination Station (LP2IL), Serang, Banten Province. At the end of the culturing period, 3 catfish were taken from each treatment for histological observation. This was carried out on the gills, kidneys, and liver, then fixed using a $10 \%$ phosphate-buffered formalin solution and 5\% ethylenediaminetetraacetic acid (EDTA). The histology preparation was then stained with hematoxylin and eosin $(\mathrm{H} \& \mathrm{E})$ and Gram stains.

\section{Data analysis}

The growth data and hematological parameters obtained at the end of rearing were analyzed using Analysis of Variance (ANOVA) and for those with differences were subjected to Duncan multiple range tests with a $95 \%$ confidence interval (Duncan 1995). In addition, the results of histological observations were analyzed descriptively.

\section{RESULTS AND DISCUSSION}

\section{Water quality}

The value of water quality in African catfish rearing is shown in Table 1. It shows that there was no significant difference $(\mathrm{P}>0.05)$ of ammonia value in catfish rearing media before (H0, H10, H20, and $\mathrm{H} 30)$ and after challenge tests (H34, H38). The difference in ammonic value occurred on day 45 , and the lowest significant ammonia value $(\mathrm{P}<0.05)$ was in treatment $A$, which was $1.91 \pm 0.17$ $\mathrm{mg} / \mathrm{L}$, then treatment $\mathrm{B}$ was $2.12 \pm 0.14 \mathrm{mg} / \mathrm{L}$ and the highest ammonia value was found in the control treatment, which was at $2.36 \pm 0.19 \mathrm{M}$. Furthermore, the addition of probiotics in African catfish rearing had no effect $(\mathrm{P}<0.05)$ on the parameters of temperature, $\mathrm{DO}$ and $\mathrm{pH}$. The values of the temperature range in the catfish rearing from day 0 to 45 ranged between 28.0 and $29.0{ }^{\circ} \mathrm{C}$ and the DO ranged between 5.1 and $6.9 \mathrm{mg} / \mathrm{L}$, while the range of the $\mathrm{pH}$ was 6.7-7.0.

\section{Growth}

The effect of the addition of the three different dosages of the probiotic Bacillus NP5 on the growth performance of African catfish is presented in Table 2 . The results showed that the highest significant African catfish biomass on the 30th day $(\mathrm{P}<0.05)$ was found in treatments $\mathrm{A}$ and $\mathrm{B}$ $(346.00 \pm 7.30 \mathrm{~g}$, and $334.17 \pm 12.28 \mathrm{~g}$, respectively), while the lowest biomass was in the control treatment at $251.43 \pm 10.73 \mathrm{~g}$. The amount of feed consumption and survival rate of African catfish on the 30th day also did not differ (P> 0.05) among the treatments. The highest significant SGR and FCR values on the 30th day $(\mathrm{P}<0.05)$ were found in the treatments with the addition of probiotics compared with the control. The highest significant FCR value $(\mathrm{P}<0.05)$ on the 30th day was also found in the probiotic treatments compared with the control. In a period of 30-45 days or after the challenge test, the highest final significant biomass value of catfish $(\mathrm{P}<0.05)$ was found in treatment A $(398.97 \pm 12.12 \mathrm{~g})$, then followed by $\mathrm{B}$ $(369.57 \pm 11.23 \mathrm{~g})$ while the lowest was found in the control treatment $(270.37 \pm 5.90 \mathrm{~g})$. The highest significant FCR value $(\mathrm{P}<0.05)$ was found in the control treatment compared with those with probiotic. The results of the survival rates were found, where the highest was found in the treatments with probiotics $(\mathrm{A}=89.82 \pm 0.30 \%$ and $\mathrm{B}=$ $83.07 \pm 7.56 \%$ ) compared with the SR from the control, which was $50.96 \pm 6.50 \%$. In the overall time period, day 0 to 45 , the highest significant biomass and SGR value ( $P$ $<0.05$ ) was found in treatment $\mathrm{A}$, then followed by $\mathrm{B}$ before the control. The SGR value obtained for treatment A was $2.02 \pm 0.07 \%$ day $^{-1}$, while the values for control and treatment $\mathrm{B}$ were $1.15 \pm 0.05 \% \mathrm{day}^{-1}$ and $1.85 \pm 0.07 \%$ day $^{-1}$, respectively. However, the highest significant FCR value $(P<0.05)$ was found in the control treatment, while the lowest found in treatment A. Furthermore, the addition of probiotics in the rearing media had a significant effect $(\mathrm{P}$ 
$<0.05)$ on the survival rate of African catfish. Based on the results, the highest SR value was obtained in the treatments with probiotics supplementation.

\section{Hematological parameters}

The results showing the hematological parameters such as the values of erythrocytes, leukocytes, hemoglobin, hematocrit, and phagocyte activity, are shown in Table 3. Based on Table 3, the values did not differ among the treatments on day 0 . However, there were highest significant values $(\mathrm{P}<0.05)$ of erythrocytes, hematocrit and phagocyte activity on day 30 found in the treatment with the probiotic supplementation, and it was more in $\mathrm{A}$ compared with B. Then on day 45, after the challenge test, the highest significant values of erythrocytes, leukocytes and phagocyte activity $(\mathrm{P}<0.05)$ were found in treatments $\mathrm{A}$ and $\mathrm{B}$. However, the highest significant value $(\mathrm{P}<0.05)$ of the leukocyte was found in treatment $\mathrm{A}$ at $6.69 \pm 0.17 \mathrm{x}$ $10^{4}$ cells $/ \mathrm{mm}^{3}$ compared with $\mathrm{B}$ at $6.46 \pm 0.06 \times 10^{4}$ cells $/ \mathrm{mm}^{3}$ and control at $5.08 \pm 0.07 \times 10^{4}$ cells $/ \mathrm{mm}^{3}$. The same trend occurred for phagocyte activity where the highest significant value $(\mathrm{P}<0.05)$ was found in treatment $\mathrm{A}$ at $65.19 \pm 0.04 \%$ compared with the control and treatment $\mathrm{B}$ at $32.21 \pm 0.18 \%$ and $44.20 \pm 0.17 \%$, respectively.

\section{Histopathology}

Histopathology is a microscopic search of disease in an organism, however, a histopathological observation involves obtaining information in the form of an organ/tissue change pictures. The histopathology results after the challenge test on the gills, liver, and kidneys of catfish are presented in Figures 1, 2, and 3.

Table 1. Water quality values of African catfish (C. gariepinus) cultured with the administration of different probiotics in the rearing media

\begin{tabular}{|c|c|c|c|c|c|}
\hline \multirow{2}{*}{ Parameter } & \multicolumn{3}{|c|}{ Treatment* } & \multirow{2}{*}{ Range } & \multirow{2}{*}{ Quality standards } \\
\hline & Control & $\mathbf{A}$ & B & & \\
\hline \multicolumn{6}{|c|}{ Ammonia (mg/L) } \\
\hline $\mathrm{HO}$ & $0.01 \pm 0.01$ & $0.01 \pm 0.02$ & $0.01 \pm 0.01$ & $0.01-0.02$ & \multirow{7}{*}{$<2.5 \mathrm{mg} / \mathrm{L}^{* *}$} \\
\hline H10 & $0.29 \pm 0.44$ & $0.04 \pm 0.04$ & $0.05 \pm 0.08$ & $0.01-0.79$ & \\
\hline $\mathrm{H} 20$ & $0.68 \pm 0.09$ & $0.65 \pm 0.12$ & $0.66 \pm 0.11$ & $0.24-0.75$ & \\
\hline $\mathrm{H} 30$ & $1.65 \pm 0.23$ & $1.34 \pm 0.28$ & $1.30 \pm 0.21$ & $1.20-1.91$ & \\
\hline H34 & $1.85 \pm 0.09$ & $1.52 \pm 0.19$ & $1.60 \pm 0.23$ & $1.35-1.95$ & \\
\hline H38 & $2.05 \pm 0.17$ & $1.75 \pm 0.32$ & $1.92 \pm 0.10$ & $1.41-2.17$ & \\
\hline H45 & $2.36 \pm 0.19^{\mathrm{b}}$ & $1.91 \pm 0.17^{\mathrm{a}}$ & $2.12 \pm 0.14^{\mathrm{ab}}$ & $1.75-2.44$ & \\
\hline \multicolumn{6}{|c|}{ Temperature $\left({ }^{\circ} \mathrm{C}\right)$} \\
\hline $\mathrm{H} 0$ & $28.00 \pm 0.00$ & $28.00 \pm 0.00$ & $28.00 \pm 0.00$ & $28.0-28.0$ & \multirow{7}{*}{$26-32{ }^{\circ} \mathrm{C} * *$} \\
\hline H10 & $28.77 \pm 0.29$ & $28.77 \pm 0.12$ & $28.80 \pm 0.10$ & $28.0-28.9$ & \\
\hline $\mathrm{H} 20$ & $28.43 \pm 0.21$ & $28.83 \pm 0.06$ & $28.87 \pm 0.06$ & $28.2-28.9$ & \\
\hline H30 & $28.53 \pm 0.35$ & $28.93 \pm 0.06$ & $28.87 \pm 0.06$ & $28.2-29.0$ & \\
\hline H34 & $28.80 \pm 0.10$ & $28.77 \pm 0.21$ & $28.83 \pm 0.21$ & $28.6-29.0$ & \\
\hline H38 & $28.93 \pm 0.06$ & $28.93 \pm 0.06$ & $29.00 \pm 0.00$ & $28.9-29.0$ & \\
\hline H45 & $29.00 \pm 0.00$ & $28.70 \pm 0.26$ & $28.87 \pm 0.15$ & $28.5-29.0$ & \\
\hline \multicolumn{6}{|l|}{$\mathrm{DO}(\mathrm{mg} / \mathrm{L})$} \\
\hline $\mathrm{HO}$ & $6.40 \pm 0.01$ & $6.41 \pm 0.01$ & $6.40 \pm 0.01$ & $6.40-6.41$ & \multirow{7}{*}{$>3 \mathrm{mg} / \mathrm{L} * *$} \\
\hline H10 & $6.43 \pm 0.38$ & $6.57 \pm 0.49$ & $6.83 \pm 0.21$ & $6.00-6.90$ & \\
\hline $\mathrm{H} 20$ & $6.20 \pm 0.26$ & $6.03 \pm 0.06$ & $6.07 \pm 0.06$ & $6.00-6.50$ & \\
\hline $\mathrm{H} 30$ & $6.03 \pm 0.06$ & $6.17 \pm 0.16$ & $6.00 \pm 0.00$ & $6.00-6.50$ & \\
\hline H34 & $6.20 \pm 0.17$ & $6.13 \pm 0.21$ & $6.05 \pm 0.35$ & $6.10-6.50$ & \\
\hline H38 & $6.17 \pm 0.25$ & $6.23 \pm 0.29$ & $6.27 \pm 0.32$ & $6.00-6.60$ & \\
\hline $\mathrm{H} 45$ & $5.23 \pm 0.35$ & $5.27 \pm 0.36$ & $5.26 \pm 0.12$ & $5.10-6.10$ & \\
\hline \multicolumn{6}{|l|}{$\mathrm{pH}$} \\
\hline Ho & $7.00 \pm 0.00$ & $7.00 \pm 0.00$ & $7.00 \pm 0.00$ & $7.00-7.00$ & \multirow{7}{*}{$6-9 * *$} \\
\hline H10 & $7.00 \pm 0.00$ & $7.00 \pm 0.00$ & $7.00 \pm 0.00$ & $7.00-7.00$ & \\
\hline $\mathrm{H} 20$ & $6.90 \pm 0.00$ & $6.90 \pm 0.00$ & $6.90 \pm 0.00$ & $6.90-6.90$ & \\
\hline H30 & $6.90 \pm 0.00$ & $6.80 \pm 0.00$ & $6.90 \pm 0.00$ & $6.80-6.90$ & \\
\hline H34 & $6.90 \pm 0.00$ & $6.90 \pm 0.00$ & $6.90 \pm 0.00$ & $6.90-6.90$ & \\
\hline H38 & $6.74 \pm 0.00$ & $6.73 \pm 0.06$ & $6.70 \pm 0.00$ & $6.70-6.80$ & \\
\hline $\mathrm{H} 45$ & $6.80 \pm 0.00$ & $6.80 \pm 0.00$ & $6.70 \pm 0.00$ & $6.70-6.80$ & \\
\hline
\end{tabular}

Note: $*$ The same superscript letter in the same row shows the effect of probiotic Bacillus NP5 that are not different (P>0.05) on the water quality values of catfish rearing. ** Bhatnagar A \& Devi P. 2013 
Table 2. Growth performance values of African catfish (C. gariepinus) cultured with the administration of different probiotics in the rearing media

\begin{tabular}{|c|c|c|c|}
\hline \multirow{2}{*}{ Day/parameter*** } & \multicolumn{3}{|c|}{ Treatment* } \\
\hline & Control & $\mathbf{A}$ & B \\
\hline \multicolumn{4}{|c|}{$0-30$ days (before the challenge test) } \\
\hline Initial biomass ( $\mathrm{g}$ ) & $160.80 \pm 0.40$ & $160.53 \pm 0.23$ & $160.73 \pm 0.31$ \\
\hline Final biomass (g) & $251.43 \pm 10.73^{\mathrm{a}}$ & $346.00 \pm 7.30^{\mathrm{b}}$ & $334.17 \pm 12.28^{\mathrm{b}}$ \\
\hline Feed intake $(\mathrm{g})$ & $193.30 \pm 14.39$ & $185.87 \pm 5.13$ & $188.03 \pm 6.93$ \\
\hline $\operatorname{SGR}\left(\% \cdot\right.$ day $\left.^{-1}\right)$ & $1.49 \pm 0.14^{\mathrm{a}}$ & $2.56 \pm 0.08^{\mathrm{b}}$ & $2.44 \pm 0.13^{\mathrm{b}}$ \\
\hline FCR & $2.14 \pm 0.13^{\mathrm{b}}$ & $1.00 \pm 0.14^{\mathrm{a}}$ & $1.09 \pm 0.07^{\mathrm{a}}$ \\
\hline $\mathrm{SR}(\%)$ & $98.33 \pm 2.89$ & $98.33 \pm 2.89$ & $98.33 \pm 2.89$ \\
\hline \multicolumn{4}{|c|}{ 30-45 days (after the challenge test) } \\
\hline Initial biomass $(\mathrm{g})$ & $251.43 \pm 10.73^{\mathrm{a}}$ & $346.00 \pm 7.30^{\mathrm{b}}$ & $334.17 \pm 12.28^{\mathrm{b}}$ \\
\hline Final biomass (g) & $270.37 \pm 5.90^{\mathrm{a}}$ & $398.97 \pm 12.12^{\mathrm{c}}$ & $369.57 \pm 11.23^{b}$ \\
\hline Feed intake $(\mathrm{g})$ & $65.57 \pm 2.29$ & $63.07 \pm 2.36$ & $62.47 \pm 2.67$ \\
\hline SGR $\left(\%\right.$. day $\left.^{-1}\right)$ & $0.49 \pm 0.14^{\mathrm{a}}$ & $0.95 \pm 0.15^{\mathrm{ab}}$ & $0.67 \pm 0.16^{\mathrm{ab}}$ \\
\hline FCR & $3.61 \pm 0.84^{\mathrm{b}}$ & $1.22 \pm 0.23^{\mathrm{a}}$ & $1.84 \pm 0.53^{\mathrm{a}}$ \\
\hline $\mathrm{SR}(\%)$ & $50.96 \pm 6.50^{\mathrm{a}}$ & $89.82 \pm 0.30^{\mathrm{b}}$ & $83.07 \pm 7.56^{\mathrm{b}}$ \\
\hline \multicolumn{4}{|l|}{ 0-45 days } \\
\hline Initial biomass (g) & $160.80 \pm 0.40$ & $160.53 \pm 0.23$ & $160.73 \pm 0.31$ \\
\hline Final biomass (g) & $270.37 \pm 5.90^{\mathrm{a}}$ & $398.97 \pm 12.12^{\mathrm{c}}$ & $369.57 \pm 11.23^{\mathrm{b}}$ \\
\hline Feed intake $(\mathrm{g})$ & $258.87 \pm 16.11$ & $248.93 \pm 6.90$ & $250.50 \pm 6.25$ \\
\hline SGR $\left(\% \cdot\right.$ day $\left.^{-1}\right)$ & $1.15 \pm 0.05^{\mathrm{a}}$ & $2.02 \pm 0.07^{c}$ & $1.85 \pm 0.07^{\mathrm{b}}$ \\
\hline FCR & $2.36 \pm 0.07^{c}$ & $1.05 \pm 0.07^{\mathrm{a}}$ & $1.20 \pm 0.04^{\mathrm{b}}$ \\
\hline SR $(\%)$ & $50.00 \pm 5.00^{\mathrm{a}}$ & $88.33 \pm 2.89^{b}$ & $81.67 \pm 7.64^{b}$ \\
\hline
\end{tabular}

Note: *The same superscript letter in the same row shows the effect of probiotic Bacillus NP5 that are not different (P> 0.05) on the growth of catfish. ** SGR (Specific Growth Rate), FCR (Feed Conversion Ratio), SR (Survival Rate)

Table 3. The value of blood profiles in of African catfish (C. gariepinus) cultured with the administration of different probiotics in the rearing media

\begin{tabular}{|c|c|c|c|}
\hline \multirow{2}{*}{ Day/parameter } & \multicolumn{3}{|c|}{ Treatment* } \\
\hline & Control & $\mathbf{A}$ & B \\
\hline \multicolumn{4}{|l|}{0 day } \\
\hline Erythrocytes (x $10^{6}$ cell $/ \mathrm{mm}^{3}$ ) & $2.81 \pm 0.05$ & $2.72 \pm 0.14$ & $2.81 \pm 0.02$ \\
\hline Leukocytes $\left(\times 10^{4}\right.$ cell $\left./ \mathrm{mm}^{3}\right)$ & $1.28 \pm 0.08$ & $1.42 \pm 0.04$ & $1.26 \pm 0.14$ \\
\hline Hemoglobin $(\mathrm{g} \%)$ & $5.79 \pm 0.28$ & $6.09 \pm 0.51$ & $5.87 \pm 0.53$ \\
\hline Hematocrit (\%) & $16.19 \pm 0.03$ & $15.79 \pm 0.74$ & $16.10 \pm 0.15$ \\
\hline Phagocyte activity (\%) & $28.31 \pm 0.06$ & $28.44 \pm 0.05$ & $28.30 \pm 0.07$ \\
\hline \multicolumn{4}{|l|}{30 days (before the challenge test) } \\
\hline Erythrocytes $\left(\mathrm{x} 10^{6}\right.$ cell $\left./ \mathrm{mm}^{3}\right)$ & $1.31 \pm 0.03^{\mathrm{a}}$ & $3.62 \pm 0.08^{c}$ & $1.57 \pm 0.04^{\mathrm{b}}$ \\
\hline Leukocytes $\left(\mathrm{x} 10^{4}\right.$ cell $\left./ \mathrm{mm}^{3}\right)$ & $5.05 \pm 0.04^{\mathrm{b}}$ & $7.14 \pm 0.10^{c}$ & $4.44 \pm 0.29^{\mathrm{a}}$ \\
\hline Hemoglobin (g\%) & $5.86 \pm 0.31^{\mathrm{a}}$ & $7.03 \pm 0.66^{\mathrm{b}}$ & $5.57 \pm 0.16^{\mathrm{a}}$ \\
\hline Hematocrit $(\%)$ & $14.77 \pm 0.21^{b}$ & $15.93 \pm 0.36^{\mathrm{c}}$ & $11.82 \pm 0.21^{\mathrm{b}}$ \\
\hline Phagocyte activity (\%) & $35.42 \pm 0.03^{\mathrm{a}}$ & $93.19 \pm 0.06^{c}$ & $55.28 \pm 0.08^{\mathrm{b}}$ \\
\hline \multicolumn{4}{|l|}{45 days (after the challenge test) } \\
\hline Erythrocytes (x $10^{6}$ cell $\left./ \mathrm{mm}^{3}\right)$ & $1.42 \pm 0.04^{\mathrm{a}}$ & $2.67 \pm 0.10^{c}$ & $2.48 \pm 0.08^{b}$ \\
\hline Leukocytes $\left(\times 10^{4}\right.$ cell $\left./ \mathrm{mm}^{3}\right)$ & $5.08 \pm 0.07^{\mathrm{a}}$ & $6.69 \pm 0.17^{c}$ & $6.46 \pm 0.06^{b}$ \\
\hline Hemoglobin $(\mathrm{g} \%)$ & $5.58 \pm 0.39^{\mathrm{a}}$ & $7.26 \pm 0.99^{\mathrm{ab}}$ & $6.03 \pm 0.49^{\mathrm{b}}$ \\
\hline Hematocrit $(\%)$ & $8.48 \pm 0.33$ & $8.20 \pm 0.23$ & $8.14 \pm 0.13$ \\
\hline Phagocyte activity (\%) & $32.21 \pm 0.18^{\mathrm{a}}$ & $65.19 \pm 0.04^{c}$ & $44.20 \pm 0.17^{\mathrm{b}}$ \\
\hline
\end{tabular}

Note: *The same superscript letter in the same row shows the effect of the probiotic Bacillus NP5 that are not different (P> 0.05) on the blood profiles of catfish. 

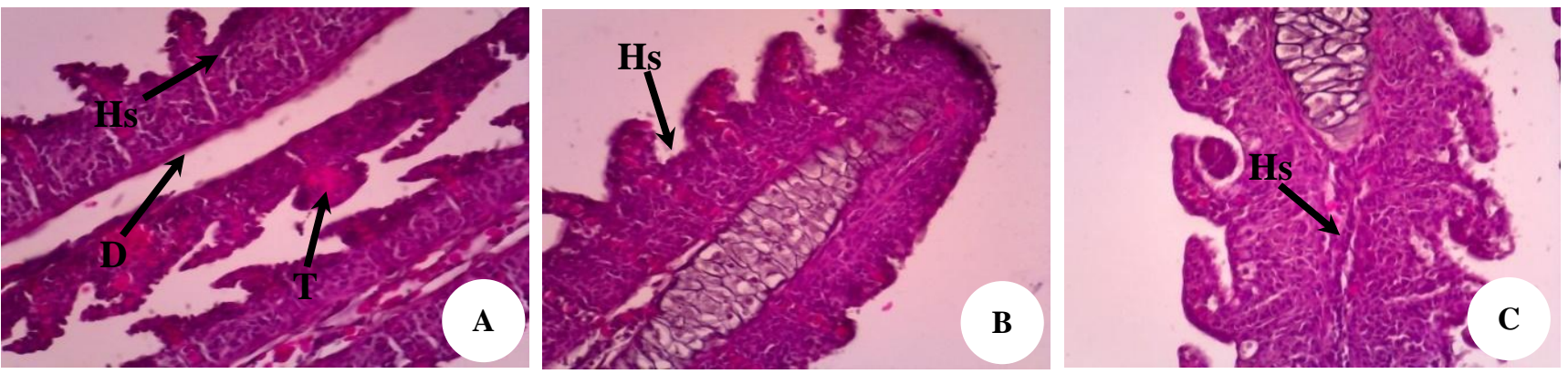

Figure 1. Histopathology of the gill of African catfish (C. gariepinus). (Magnification of 400x). The control (C) treatment shows the condition of histological changes in the form of hyperplasia (Hs), desquamation (D), and telangiectasia (T). Treatment A and B show the condition of histological changes in the form of hyperplasia (Hs)
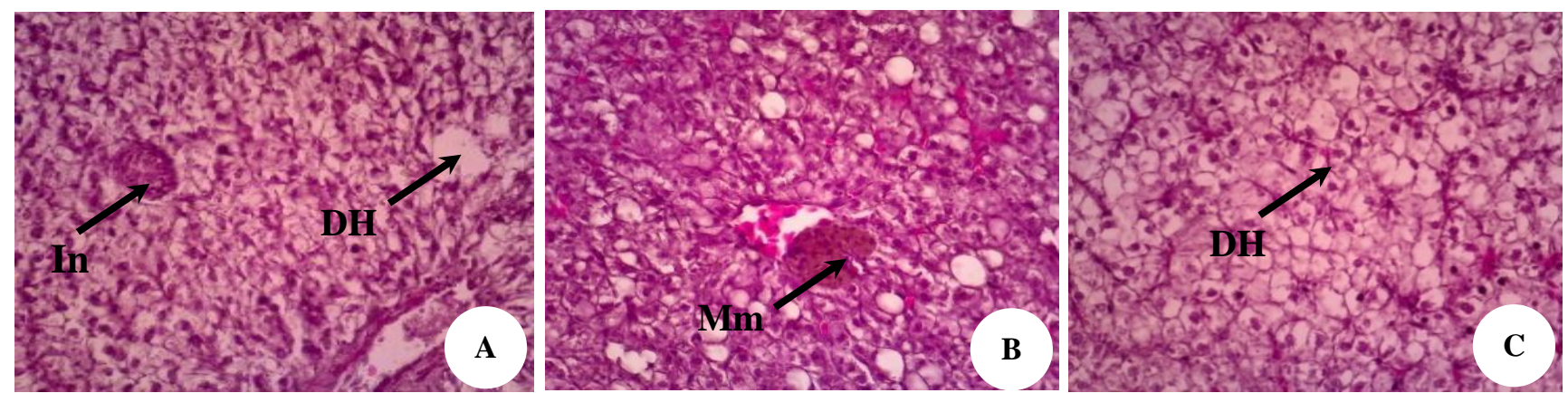

Figure 2. Histopathology of the liver of African catfish (C. gariepinus) (400x magnification). The control (C) treatment shows the condition of histological changes in the form of hydropic degeneration (DH) and inflammation infiltration (In). Treatment A shows the condition of histological changes in the form of melanomacrophage $(\mathrm{Mm})$ and treatment B shows the conditions of histological changes in the form of hydropic degeneration (DH).

\section{Discussion}

Ammonia is derived from leftover feed and feces of fish (Randall and Tsui 2002) or the decomposition of organic matter by microorganisms (Kir et al. 2016). The effect of Bacillus NP5 as a probiotic on African catfish rearing media is presented in Table 1 . The results showed that the ammonia value increased as the day progresses and the ammonia value in probiotic treatment was better than the control. This result might be related to the role of probiotic in nitrification and denitrification process in the fish water culture. Boyd and Gross (1998) reported that probiotic application increased nitrification and denitrification of organic matter in the water. The addition of Bacillus probiotic was reported to decrease the value of ammonia and nitrite in white shrimp rearing (Nimrat et al. 2012). Zokaeifar et al. (2014) noted that the administration of $B$. subtilis of $10^{8} \mathrm{CFU} / \mathrm{mL}$ in the water could reduce concentration of ammonia, nitrite, and nitrate of shrimp culture. The best ammonia value on the 45 th day was found in treatment A. Based on these results, the treatment of the rearing media with Bacillus NP5 of $1 \times 10^{9} \mathrm{CFU} / \mathrm{mL}$, could reduce the amount of ammonia dissolved in it. Similarly, Banerjee and Ray (2017) stated that the application of probiotics could eliminate ammonia and nitrite through nitrification in the fish environment. This is in line with the research conducted by Yang et al. (2011), which stated that the Bacillus sp. could convert ammonia to nitrogen under aerobic conditions. A similar result was reported in the previous study that the total ammonia in the rearing media of fish or shrimp, was lower in the one treated with probiotic compared with the control (Banerjee et al. 2010; Nimrat et al. 2011; Devaraja et al. 2013; Mahmud et al. 2016). In addition, the low ammonia in treatment $A$ was believed to be related to the FCR value in this treatment. The results showed that the lowest significant FCR value was found in this treatment. This might be due to good water quality in this treatment so that the value of FCR increases. According to Kir et al. (2019), good water quality is an important factor for fish growth in any aquaculture system, and ammonia is one of the toxic compounds which decreases the quality of water used in fish rearing. This supports the statement of NRC (2011) that low feed conversion values are indications that the feeds were used optimally.

Temperature and $\mathrm{pH}$ are factors that affect the activity of bacteria to oxidase ammonium in the water (Esoy et al. 1998; Hastuti 2011). The results also showed that there were no significant differences in temperature and $\mathrm{pH}$ among the treatments. This indicates that the ammonia value obtained in this study not related to temperature and $\mathrm{pH}$. Based on the research conducted by Bhatnagar and Devi (2013), the temperature and $\mathrm{pH}$ obtained in this research are still within the range needed in catfish rearing. Similar results were also reported by Abdul-El-Atta et al. 
(2019) that the addition of Lactobacillus plantarum has no effect on temperature, dissolved oxygen, and $\mathrm{pH}$ of tilapia rearing media. Gupta et al. (2016) also stated that the application of $B$. coagulans had no effect on the temperature, $\mathrm{pH}$, and $\mathrm{DO}$ values of freshwater prawn rearing media. The similar result was observed in the research conducted by Nimrat et al. (2012) on white shrimp (Litopenaeus vannamei), Madani et al. (2018) on white shrimp and Elsabagh (2018) on tilapia, that the provision of probiotics did not affect on the temperature of the fish rearing media. Zhou et al. (2009) also reported that the addition of probiotic $B$. coagulans SC8168 had no effect on the $\mathrm{pH}$ of larvae shrimp (Penaeus vannamei) rearing media.

The results on growth performance and feed conversion showed a significant $(\mathrm{P}<0.05)$ increase with the addition of Bacillus NP5 in African catfish rearing media for all periods. This is believed to be due to the role of probiotics in converting ammonia in African catfish rearing media, leading to optimal growth. The better growth performance in the treatments with probiotics is believed to be related not only to the environmental conditions but also to the health status (Xiong et al. 2016; Chumpol et al. 2017). Furthermore, the results of this research showed that the amount of feed consumption was not significant $(\mathrm{P}>0.05)$ among the treatments for the entire period. These corroborate the results of previous research which stated that the addition of probiotics to rearing media and feed did not affect fish appetite or feed palatability (Nargesi et al. 2019). There was no significant difference $(P>0.05)$ in the survival rate at the initial period (0-30 days). However, the survival rate in the treatment with probiotic was higher compared with the control after the challenge test period with A. hydrophila (30-45 days). This is an indication that probiotic Bacillus NP5 could improve the immune system of African catfish thereby making it more resistant to bacterial attacks. According to Dawood et al. (2018) and Zorriehzahra et al. (2016), the mechanism of action of probiotics in converting suppressing the growth of pathogenic bacteria is due to its ability to inhibit the colonization of these bacteria by producing bacteriostatic compounds such as bacteriocins, hydrogen peroxide, proteases, and lysozyme. Probiotics increase the immune response through physiological modulation (Adel et al. 2017). Al-Hisnawati et al. (2019) also reported that the administration of Pediococcus acidilactici MA18/5M as probiotic can modulate the microbiota and increase the innate immune response of rainbow trout. Similar results were reported in several studies that the addition of probiotics increased the survival rate and immune response of fish after challenge test, such as in juvenile white shrimp, L. vannamei against Vibrio harveyi infection (Zokaeifar et al. 2014), freshwater prawn infected with Vibrio harveyi (Gupta et al. 2016), Pacific white shrimp against $V$. harveyi (Hamsah et al. 2019) and $V$. parahaemolyticus (Kewcharoen and Srisapoome 2019), hybrid grouper infected by $V$. harveyi (Li et al. 2019), tilapia infected by Streptococcus agalactiae (Zhu et al. 2019), Japanese eel against A. hydrophila (Park et al. 2019).

The hematological parameters are used to detect physiological changes in fish bodies due to pathogen attack (Al-dohail et al. 2009). In this research, the value of erythrocytes, leukocytes, and phagocyte activity significantly $(\mathrm{P}<0.05)$ increased in the treatments with probiotics after A. hydrophila infection (45 days). This indicates that catfish in rearing media with probiotics have a better immune response. This result is thought to be related to the role of probiotics in the modulation of innate immune responses. Probiotic can increase innate immune systems such as neutrophils (Hoseinifar et al. 2018), monocytes (Aly et al. 2008), macrophage (Kumar et al. 2008), and leucocytes (Korkea-aho et al. 2012). It corroborates the results of previous research that the addition of probiotic Bacillus NP5 could increase the value of erythrocytes, leukocytes, and phagocytic activity in tilapia infected with Streptococcus algalactiae (Agung et al. 2015) and P. hypopthalmus infected with A. hydrophila (Tamamdusturi et al. 2016). The results showed that the value of erythrocytes after the challenge test decreased for all treatments. This is due to A. hydrophila infection which produced both exotoxin and endotoxin enzymes leading to the lysis of red blood cells (Zhang et al. 2014). These results are consistent with Agung et al. (2015) who reported that pathogen infection caused a decrease in erythrocyte values in tilapia.
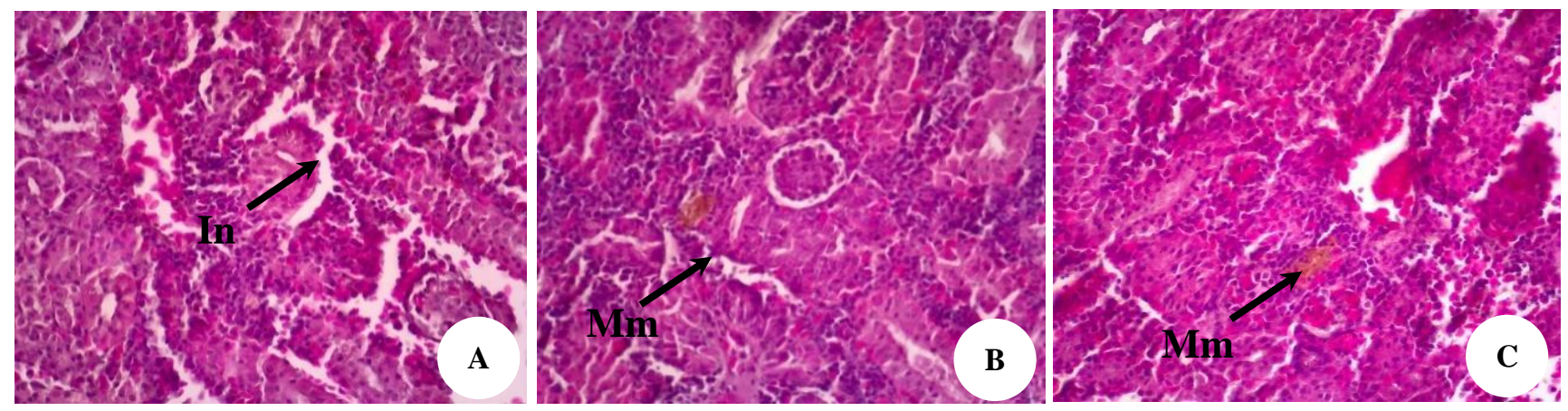

Figure 3. Histopathology of the kidney of African catfish (C. gariepinus) (400x magnification). The control (C) treatment shows the condition of histological changes in the form of inflammatory cell infiltration (In). Treatment A and treatment B show the condition of histological changes in the form of melanomacrophage $(\mathrm{Mm})$ 
According to Uribe et al. (2011), leukocytes are part of the body defense system which is nonspecific. The results showed that at the end of the rearing period, treatment A had the highest significant $(\mathrm{P}<0.05)$ leukocytes among the treatments. These indicate that African catfish with probiotic Bacillus NP5 of $1 \times 10^{9} \mathrm{CFU} / \mathrm{mL}$ have a better body defense mechanism against pathogen attacks. Similar results were obtained by da Paixão et al. (2017) who reported that the addition of commercial probiotics $B$. subtilis and Saccharomyces cerevisiae increased leukocyte values after infection with Streptococcus agalactiae. Furthermore, the value of phagocytic activity was higher in the treatments with probiotics. According to Balcazar et al. (2006), phagocytic activity is an inflammatory response which serves as initial resistance before the production of antibody.

Furthermore, the results showed there was damage to the African catfish gill tissue after infection with $A$. hydrophila. This is shown by the tissue changes in the form of hyperplasia in all gills of African catfish in the treatments. Laith and Najiah (2013) stated that the symptoms of $A$. hydrophila attacks are limp fish, decreased appetite, necrosis, and hypertrophy of the skin, hyperplasia and infiltration of leukocytes in the gills, inflammation in the kidneys, liver, and spleen. In addition to hyperplasia, desquamation and telangiectation occur in the gills of African catfish in the control. This telangeactasis occurs in the gills of fish in poor water quality, attacked by pathogens, as well as with accumulation of metabolic and chemical pollutants (Robert 2001). The histology results of the liver showed more histological changes in the control. These changes include hydropic degeneration and inflammation infiltration. However, there was melanomacrophage in treatment A while B had hydropic degeneration. Inflammatory cell infiltration and melanomacrophage occur in the kidneys of African catfish infected with A. hydrophila. According to Mokhtar (2017), hydropic degeneration, melanomacrophages, and inflammatory infiltration are all indications of tissue damage due to pathogen infection. The degree of damage to all probiotic treatments only occurs focally. This is believed to be due to the effect of the probiotics in rearing media which only reduces the number of A. hydrophila without causing severe organ damage.

Based on the results, it could be concluded that the addition of probiotic Bacillus NP5 on rearing media significantly improved the growth performance, survival rates, and resistance of African catfish to A. hydrophila infection. The degree of tissue damage due to $A$. hydrophila infection in the treatments with probiotics supplementation was smaller compared with that of the control. Also, the probiotic of $1 \times 10^{9} \mathrm{CFU} / \mathrm{mL}$ (A) significantly resulted in the best SGR and FCR at $2.02 \pm$ $0.07 \%$ day $^{-1}$ and $1.05 \pm 0.07$ respectively. Similarly, the highest number of leukocytes at $6.69 \pm 0.17 \times 10^{4}$ cells $/ \mathrm{mm}^{3}$ and phagocyte activity at $65.19 \pm 0.04 \%$ were found in treatment $\mathrm{A}$. Furthermore, the addition of probiotics of $1 \times 10^{9} \mathrm{CFU} / \mathrm{mL}$ resulted in the lowest ammonia value at $1.91 \pm 0.17 \mathrm{mg} / \mathrm{L}$. However, the administration of probiotics did not affect the temperature, $\mathrm{DO}$ and $\mathrm{pH}$ values of the African catfish rearing media.

\section{ACKNOWLEDGEMENTS}

We would like to thank Histopathology Laboratory of LP2IL, Serang-Indonesia for the guidance in histology preparation. We also thank Baros Fish Seed Center (BBI Baros), Serang Regency, Banten for providing African catfish in the present study.

\section{REFERENCES}

Abdul-El-Atta ME, Abdel-Tawwab M, Abdel-Rezek N, Abdelhakim TMN. 2019. Effects of dietary probiotic Lactobacillus plantarum and whey protein concentrate on the productive parameters, immunity response, and susceptibility of Nile tilapia, Oreochromis niloticus (L), to Aeromonas sobria infection. Aquac Nutr 25: 1367-1377.

Adel M, Yeganeh S, Dawood MAO, Safari R, Radhakrishnan S. 2017. Effect of Pediococcus pentosaceus supplementation on growth performance, intestinal microflora and disease resistance of white shrimp, Litopenaeus vannamei. Aquac Nutr 23: 1401-1409.

Al-Dohail MA, Hashim R, Aliyu-Paiko M. 2009. Effects of the probiotic, Lactobacillus acidophilus, on the growth performance, haematology parameters and immunoglobulin concentration in African Catfish (Clarias gariepinus, Burchell 1822) fingerling. Aquac Res 40: 16421652.

Al-Hisnawati A, Rodiles A, Rawling MD, Catex M, Waines P, Gioacchini G, Carnevalli O, Merrifiled DL. 2019. Dietary probiotic Pediococcus acidilactici MA18/5M modulates the intestinal microbiota and stimulates intestinal immunity in rainbow trout (Oncorhynchus mykiss). J World Aquac Soc 50: 1133-1151.

Aly SM, Ahmed YA-G, Ghareeb AA-A, Mohamed MF. 2008. Studies on Bacillus subtilis and Lactobacillus acidophilus, as potential probiotics, on the immune response and resistance of Tilapia nilotica (Oreochromis niloticus) to challenge infections. Fish Shellfish Immunol 25: 128-136.

Agung AL, Widananrni, Yuhana M. 2015. Application of microencapsulated probiotic Bacillus NP5 and prebiotic mannan oligosaccharide (MOS) to prevent Streptococcosis on tilapia Oreochromis niloticus. Res J Microbiol 10: 571-581.

Amin M, Bolch CJS, Adams MB, Burke CM. 2019. Growth enhancement of tropical abalone, Haliotis asinina $\mathrm{L}$, through probiotic supplementation. Aquac Int 28: 463-475.

Anderson DP, Siwicki AK. 1995. Basic hematology and serology for fish health program. Proceeding of the second symposium on disease in Asian aquaculture, October 25-29, 1995.

Arani MM, Salati AP, Safari O, Keynanshokooh. 2019. Dietary supplementation effects of Pediococcus acidilactici as probiotics on growth performance, digestive enzyme activities and immunity response in zebrafish (Danio rerio). Aquac Nutr 25: 854-861.

APHA. 1998. Standard methods for the examination of the water and wastewater $\left(22^{\text {nd }}\right.$ ed.). American public health association. Washington DC., USA.

Avnimelech Y, Ritvo G. 2003.Shrimp and fish pond soils: processes and management. Aquaculture 220: 549-567.

Balcazar JL, Blas ID, Ruiz-Zarzuela I, Cunningham D, Vendrell D, Múzquiz JL. 2006. The role of probiotics in aquaculture. Vet Microbiol 114: 173-186.

Banerjee S, Khatoon H, Shariff M, Yusoff F Md. 2010. Enhancement of Penaeus monodon shrimp postlarvae growth and survival without water exchange using marine Bacillus pumilus and periphytic microorganism. Fish Sci 76: 481-487.

Banerjee G, Ray AK. 2017. The advancement of probiotics research and its application in fish farming industries. Res Vet Sci 115: 66-77.

Bhatnagar A, Devi P. 2013. Water quality guidelines for the management of pond fish culture. Int J Environ Sci 3: 1980-2009. 
Blaxhall PC, Daisley KW. 1973. Routine hematological methods for use with fish blood. J Fish Biol 5: 771-781.

Boyd CE, Gross A. 1998. Use of probiotic for improving soil and water quality in aquaculture ponds. In: Flegel TW (eds) Advances in shrimp biotechnology. National center for genetic engineering and biotechnology, Bangkok 101-105.

Boyd CE, Mcnevin AA. 2014. Aquaculture resource Use, and the environment. Wiley Blackwell, Canada. 377 pp.

Cerezuela R, Guardiola FA, Gonzales P, Meseguer J, Esteban MA. 2012 Effects of dietary Bacillus subtilis, Tetraselmis chuii, and Phaeodactylum tricornutum, singularly or in combination, on the immune response and disease resistance of sea bream (Sparus aurata L.) Fish Shellfish Immunol 33: 342-349.

Chumpol S, Kantachote D, Nitoda T, Kanzaki H. 2017. The roles of probiotic purple nonsulfur bacteria to control water quality and prevent acute hepatopancreatic necrosis disease (AHPND) for enhancement growth with higher survival in white shrimp (Litopenaeus vannamei) during cultivation. Aquaculture 473: 327336.

Dawood MAO, Koshio S, Abdel-Daim MM, Doan HV. 2018. Probiotic application for sustainable aquaculture. Rev Aquac 11: 1-8.

Darafsh F, Soltani M, Abdolhay HA, Mehrejan MS. 2019. Improvement of growth performance, digestive enzymes and body composition of Persian sturgeon (Acipenser persicus) following feeding on probiotics: Bacillus licheniformis, Bacillus subtilis and Saccharomyces cerevisiae. Aquac Res 51: 957-964.

da Paixão AEM, dos Santos JC, Pinto MS, Pereira DSP, de Oliveira Ramos CEC, Cerqueira RB, da Silva RF. 2017. Effect of commercial probiotics (Bacillus subtilis and Saccharomyces cerevisiae) on growth performance, body composition, hematology parameters, and disease resistance against Streptococcus agalactiae in tambaqui (Colossoma macropomum). Aquac Int 25(6): 2035-2045.

Devaraja T, Banerjee S, Yusoff F, Shariff M, Khatoon H. 2013. A holistic approach for selection of Bacillus spp. as a bioremediator for shrimp postlarvae culture. Turk J Biol 37: 92-100.

Duncan DB. 1955. Multiple range and multiple 'F' tests. Biometrics 11: $1-42$.

Elsabagh M, Mohamed R, Moustafa EM, Hamza A, Farrag F, Decamp O, Dawood MAO, Eltholth M. 2018. Assessing the impact Bacillus strains mixture probiotic on water quality, growth performance, blood profile and intestinal morphology of Nile-Tilapia, Oreochromis niloticus. Aquac Nutr 24: 1613-1622.

Esoy A, Odegaard H, Bentzen G. 1998. The effect of sulphide and organic matter on the nitrification activity in biofilm process. Water Sci Technol 37: 115-122.

Febrianti D, Yuhana M, Widanarni. 2016. Dietary symbiotic microcapsule influence the immune responses, growth performance and microbia population to white spot syndrome virus in pacific white shrimp (Litopenaeus vannamei). J Fish Aquat Sci $11: 28-42$.

Food and Agriculture Organization of the United Nations (FAO). 2018 The state of world fisheries and aquaculture: opportunities and challenges. Roma: FAO. 223 pp.

Garcia-mendoza, Caceres-Martinez, Vaquez-Yeomans, Cruz-Flores. 2019. Bacteriological water quality of recirculating aquatic system fo maintenance of yellowtail amberjack Seriola lalandi. J World Aquac Soc 50: 934-953.

Giri SS, Sen SS, Sukumaran V. 2012. Effect of dietary supplementation of potential probiotic Pseudomonas aeruginosa VSG-2 on the innate immunity and disease resistance of tropical freshwater fish, Labeo rohita. Fish Shellfish Immunol 32: 1135-1140.

Gomez-Gil B, Roque A, Turnbull JF. 2000. The use and selection of probiotic bacteria for use in the culture of larval aquatic organisms. Aquaculture 191: 259-270.

Gupta A, Verma G, Gupta P. 2016. Growth performance, feed utilization, digestive enzyme activity, innate immunity and protection agains Vibrio harveyi of freshwater prawn, Macrobrachium rosenbergii fed diets supplemented with Bacillus coagulans. Aquac Int 24: 13791392.

Hamsah H, Widanarni, Alimuddin, YUhana M, Junior MZ, Hidayatulloh D. 2019. Immune response and resistance of Pacific white shrimp larvae administered probiotic, prebiotic, and symbiotic larvae trough thebio-encapsulation of Artemia sp. Aquac Int 27: 567-580.

Hastuti YP. 2011. Nitrification and denitrification in pond. Jurnal Akuakultur Indonesia 10: 89-98. [Indonesian]
Hoseinifar SH, Sun Y-Z, Wang A, Zhou Z. 2018. Probiotics as means of disease control in aquaculture, a review of current knowledge and future perspectives. Front Microbiol 9: Article 2429.

Huisman EA. 1987. Principles of fish production. Department of Fish Culture and Fisheries, Wageningen Agriculture University, Wageningen, Netherland.

Iswanto B, Suprapto R, Imron. 2019. Establishing a base population of individual selection for low maintenance requirements in terms of dietary protein level in the African catfish (Clarias gariepinus). Indon Aquac J 14: 23-29.

Jang JW, Lee JM, Hasan MT, Lee B-J, Lim SG, Kong I-S. 2019. Effects probiotic supplementation of a plant-based protein diet on intestinal microbial diversity, digestive enzyme activity, intestinal structure, and immunity in olive flounder (Paralichthys olivaceus). Fish Shellfish Immunol 92: 719-727.

Kewcharoen W, Srisapoome P. 2019. Probiotic effects of Bacillus spp. from Pacific white shrimp (Litopenaeus vannamei) on water quality and shrimp growth, immune responses, and resistance to Vibrio parahaemolyticus (AHPND strains). Fish Shellfish Immunol 94: 175189.

Kir M, Topuz M, Sunar MC, Topuz H. 2016. Acute toxicity of ammonia in Meagre (Argyrosomus regius Asso, 1801) at different temperatures. Aquac Res 47: 3593-3598.

Kir M, Sunar MC, Gok MG. 2019. Acute ammonia toxicity and the interactive effects of ammonia and salinity on the standard metabolism of European sea bass (Dicentrarchus labrax). Aquaculture 511: 734273

Korkea-aho TL, Papadopoulou A, Heikkinen J, Wright AV, Adams A, Austin B, Thomson KD. 2012. Pseudomonas M162 confers protection against rainbow trout fry syndrome by stimulating immunity. J Appl Microbiol 113: 24-35.

Kuebutornye FKA, Abarike ED, Lu Y. 2019. A review on the application of Bacillus as probiotics in aquaculture. Fish Shellfish Immunol 87: 820-828.

Kumar R, Mukherjee SC, Ranjan R, Nayak SK. 2008. Enhances innate immune parameters in Labeo rohita (Ham.) following oral administration of Bacillus subtilis. Fish Shellfish Immunol 24: 168172

Laith AR, Najiah M. 2013. A. hydrophila: antimicrobial susceptibility and histopathology of isolates from diseased catfish, Clarias gariepinus (Burcell). Aquac Res Dev 5: 1-7.

Li J, Wu Z-B, Zhang Z, Zha J-W, Qu S-Y, Qi X-Z, Wang G-X. 2019. Effects of potential probiotic Bacillus velezensis $\mathrm{K} 2$ on growth, immunity, and resistance to Vibrio harveyi infection of hybrid grouper (Epinephelus lanceolatus $\mathrm{x}$ E. fuscoguttatus). Fish Shellfish Immunol 93: 1047-1055.

Madani NSH, Adorian TJ, Farsani HG, Hoseinifar SH. 2018. The effects of dietary probiotic Bacilli (Bacillus subtilis and Bacillus licheniformis) on growth performance, feed efficiency, body composition, and immune parameters of white leg shrimp (Litopenaeus vannamei) postlarvae. Aquac Res 49: 1926-1933.

Mahmud S, Ali ML, Alam MA, Rahman M, Jorgensen NOG. 2016. Effect of probiotic and sand filtration treatments on water quality and growth of tilapia (Oreochromis niloticus) and pangas (Pangasianodon hypophthalmus) in earthen ponds of southern Bangladesh. J Appl Aquac 28 (3): 199-212.

Makled SO, Hamdan AM, El-Sayed A-F. 2019. Effect of dietary supplementation of a marine thermotolerant bacterium, Bacillus paralicheniformis SO-1, on growth performance and immune responses of Nile tilapia, Oreochromis niloticus. Aquac Nutr 25: 817827.

Ministry of Marine Affairs and Fisheries of the Republic Indonesia. 2019. Kelautan dan perikanan dalam angka. Retrieved from https: //kkp.go.id/setjen/satudata/artikel/9669-kelautan-dan-perikanandalam-angka-2018-telah-terbit. [Indonesian]

Mokhtar DM. 2017. Fish histology from cells to organs. Apple Academic Press, Canada. 239pp

Nandi A, Banerjee G, Dan SK, Ghosh K, Ray AK. 2017. Probiotic efficiency of Bacillus sp. in Labeo rohita challenged by Aeromonas hydrophila: assessment of stress profile, haetomato-biochemical parameters and immune responses. Aquac Res 48: 4334-4345.

National Research Council [NRC]. 2011. Nutrient requirements of fish and shrimp. In: The National Academies Press, Washington, DC. 376pp.

Nasrulloh H, Nababab YI, Yanti DH, Hardiantho D, Nuryati S, Zairin M, Ekasari J, Alimudin. 2019. Identification and expression analysis of c- 
type and g-type lysozymes genes after Aeromonas hydrophila infection in African catfish. Jurnal Akuakultur Indonesia 18: 110-119. [Indonesian]

Nargesi EA, Falahatkar B, Sajjadi MM. 2020. Dietary supplementation of probiotic and influence on feed efficiency, growth parameters and reproductive performance in female rainbow trout (Oncorhynchus mykiss) broodstock. Aquac Nutr 26: 98-108

Ngaddi A, Jusadi D, Wasjan, Supriyono E. 2019. Evaluation of monosodium glutamate supplementation on physiological response, growth performance, and feed utilization in North African catfish Clarias gariepinus (Burchell, 1822). Jurnal Ikhtiologi Indonesia 19: 337-348. [Indonesian]

Nimrat S, Boonthai T, Vuthiphandchai V. 2011. Effects of probiotic forms, compositions of and mode of probiotic administration on rearing of Pacific white shrimp (Litopenaeus vannamei) larvae and postlarvae. Anim Feed Sci Technol 169: 244-258.

Nimrat S, Suksawat S, Boonthai T, Vuthiphandchai V. 2012. Potential Bacillus probiotics enhance bacterial numbers, water quality and growth during early development of white shrimp (Litopenaeus vannamei). Vet Microbiol 159: 443-450.

Nurhayati D, Yuhana M. 2015. Dietary synbiotic influence on the growth performances and immune responses to co-infection with infectious myonecrosis virus and Vibrio harveyi in Litopenaeus vannamei. J Fish Aquat Sci 10(1): 13.

Park Y, Kim H, Won S, Hamidoghli A, Hasan MT, Kong I-S, Bai SC 2019. Effects of two dietary probiotics (Bacillus subtilis or Licheniformis) with two prebiotics (mannan or fructo oligosaccharide) in Japanese eel, Anguilla japonica. Aquac Nutr 26: 316-327.

Putra AN, Widanarni. 2015. Screening of amylolytic bacteria as candidates of probiotics in tilapia Oreochromis sp.. Res J Microbio 10: $1-13$

Putra AN, Widanarni, Utomo NBP. 2015. Growth performance of tilapia (Oreochromis niloticus) fed with probiotic, prebiotic and synbiotic in diet. Pak J Nutr 14: 263-268.

Putra AN, Romdhonah Y. 2019. Effects of dietary Bacillus NP5 and sweet potato extract on growth and digestive enzyme activity of dumbo catfish, Clarias sp.. Jurnal Akuakultur Indonesia 18: 80-88. [Indonesian]

Ramadhani DK, Widanarni, Sukenda. 2019. Microencapsulation of probiotic and its applications with prebiotic in Pacific white shrimp larvae through Artemia sp. Jurnal Akuakulture Indonesia 18: 130-140. [Indonesian]

Randall DJ, Tsui TKN. 2002. Ammonia toxicity in fish. Mar Pollut Bull 45: 17-23.

Ren Y, Guo G, Zhou S, Li C. 2019. Water quality and nitrogen budget in turbot Scophthalmus maximus culture system supplemented with lactic acid bacteria. Aquac Res 50: 2743-2750.

Roberts RJ. 2001. Fish pathology. Edisi III. Saunders, W.B. London. Edinburgh, Philadelphia, St. Louis, Sydney, Toronto, 472 pp.

Tachibana L, Telli GS, Dias DC, Goncalves GS, Ishikawa CM, Cavalcante RB, Natori MM, Hamed SB, Ranzani-Paiva MJT. 2020. Effect of feeding strategy of probiotic Enterococcus faecium on growth performance, hematologic, biochemical parameters and nonspecific immune response of Nile tilapia. Aquac Rep 16: 100277.

Tamamdusturi R, Widanarn, Yuhana M. 2016. Administration of microencapsulated probiotic Bacillus sp. NP5 and prebiotic mannan oligosaccharide for prevention of Aeromonas hydrophila infection on Pangasianodon hypophthalmus. J Fish Aquat Sci 11: 67-76.

Tsai C-T, Chi C-C, Liu C-H. 2019. The growth and apparent digestibility of white shrimp, Litopenaeus vannamei, are increased with the probiotic, Bacillus subtilis. Aquac Res 50: 1475-1481.

Uribe C, Folch H, Enriquez R, Moran G. 2011. Innate and adaptive immunity in teleost fish: A review. Vet Med 56: 486-503.

Utami DAS, Widanarni, Suprayudi MA. 2015. Quality of dried Bacillus NP5 and its effect on growth performance of tilapia Oreochromi niloticus. Pak J Biol Sci 18: 88-93.

Valipour A, Nedaei S, Noori A, Khanipour AA, Hoseinifar SH. 2019. Dietary Lactobacillus plantarun affected some immune parameters, air-exposure stress response, intestinal microbiota, digestive enzyme activity and performance of narrow clawed crayfish (Astacus leptodactylus, Eschscholtz). Aquaculture 504: 121-130.
Verschure L, Rombaut G, Sorgeloos P, Verstrate W. 2000. Probiotic bacteria as biological control agents in aquaculture. Microbiol Mol Biol Rev 64: 655-671.

Wada S, Atami H, Kurata O, Hatai K, Kasuya K, Watanabe Y, Fukuda H. 2011. Histopathology of gill lesions of ayu Plecoglossus altivelis clinically diagnosed with 'Boke' Disease. Fish Pathol 46: 59-61.

Wang Y-B, Tian Z-Q, Yao J-T, Li W-F. 2008. Effect of probiotics, Enterococcus faecium, on tilapia (Oreochromis niloticus) growth performance and immune response. Aquaculture 277: 203-207.

Wedemeyer GA, Yasutake. 1977. Clinical methods for the assessment on the effect of environmental stress on fish health. US: U.S Fish and Wildlife service. 89p.

Widanarni, Yuniasari D, Sukenda, Ekasari J. 2010. Nursery culture performance of Litopenaeus vannamei with probiotics addition and different $\mathrm{C} / \mathrm{N}$ ration under laboratory condition. Hayati J Biosci 17: 115-119.

Widanarni, Yuhana M, Muhamad A. 2014. Bacillus NP5 improves growth performance and resistance against infectious myonecrosis virus in white shrimp Litopenaeus vannamei. Ilmu Kelautan 19: 211-218. [Indonesian]

Xie J-J, Liu Q-Q, Liao S, Fang H-H, Yin P, Xie S-W, Tian L-X, Liu Y-J, Niu J. 2019. Effects of dietary mixed probiotics, on growth, nonspecific immunity, intestinal morphology and microbiota of juvenile pacific white shrimp, Litopenaeus vannamei. Fish Shellfish Immunol 90: 456-465.

Xiong J, Dai W, Li L. 2016. Advances, challenges, and direction in shrimp disease control: the guidelines from an ecological perspective. Appl Microbiol Biotechnol 100: 6947-6954.

Yang XP, Wang SM, Zhang DW, and Zhou LX. 2011. Isolation and nitrogen removal characteristics of an aerobic heterotrophic nitrifying-denitrifying bacterium, Bacillus subtilis A1. Bioresour Technol $102: 854-862$.

Yang G, Cao H, Jiang W, Hu B, Jian S, Wen C, Kajbaf K, Kumar V, Tao Z, Peng M. 2019. Dietary supplementation of Bacillus cereus as probiotics in Pengze crucian carp (Carassius auratus var. Pengeze): Effects on growth performance, fillet quality, serum biochemical parameters and intestinal histology. Aquac Res 50: 2207-2217.

Zhang X, Yang W, Wu H, Gong X, Li A. 2014. Multilocus sequence typing revealed a clonal lineage of Aeromonas hydrophila caused motile Aeromonas septicemia outbreaks in pond-cultured cyprinid fish in an epidemic area in central China. Aquaculture 432: 1-6.

Zhang H, Sun Z, Liu B, Xuan Y, Jiang M, Pan Y, Zhang Y, Gong Y, Lu D, Kumar D, Hu X, Cao G, Xue R, Gong C. 2016. Dynamic changes of microbial communities in Litopenaeus vannamei culture and the effects of environmental factors. Aquaculture 455: 97-108.

Zhang Z, Yang Z, Zheng G, Lin Q, Zhuo X, Zhang G. 2019. Effect of addition of sucrose and probiotics on whiteleg shrimp Litopenaeus vannamei postlarvae performance, water quality, and microbial community. North Am J Aquac 82: 45-53.

Zhao C, Zhu J, Hu J, Dong X, Sun L, Zhang X, Miao S. 2019. Effects of dietary Bacillus pumilus on growth performance, innate immunity and digestive enzymes of giant freshwater prawns (Macrobarachium rosenbergii). Aquac Nutr 25: 712-720.

Zhou X-X, Wang Y-B, Li W-F. 2009. Effect of probiotic on larvae shrimp (Penaeus vannamei) based on water quality, survival rate, and digestive enzyme activities. Aquaculture 287: 349-353.

Zhu C, Yu L, Liu W, Jiang M, He S, Yi G, Wen H, Liang X. 2019. Dietary supplementation with Bacillus subtilis LT3-1 enhances the growth, immunity and disease resistance against Streptococcus agalactiae infection in genetically improved farmed tilapia, Oreochromis niloticus. Aquac Nutr 25: 1241-1249.

Zokaeifar H, Babaei N, Saad CR, Kamarudin MS, Sijam K, Balcazar JL. 2014. Administration of Bacillus subtilis strains $\mathrm{n}$ the rearing water enhances the water quality, growth performance, immune response, and resistance against Vibrio harveyi infection in juvenile white shrimp, Litopenaeus vannamei. Fish Shellfish Immunol 36: 68-74.

Zorriehzahra MJ, Delshad ST, Adel M, Tiwari R, Karthik K, Dharma K. Lazado CC. 2016. Probiotics as beneficial microbes in aquaculture: an update on their multiple modes of action: a review. Vet Q 36: 228241. 